\title{
Noctiluca Scintillans (Dinophyceae) in Central Coastal Waters of Tanzania: A New Phytoplankton Record for the Area
}

\author{
Charles Lugomela \\ Department of Fisheries Science and Aquaculture, Faculty of Aquatic Sciences and Technology, University of \\ Dar es Salaam, P.O. Box 35064 Dar es Salaam, Tanzania
}

\begin{abstract}
Key words: Noctiluca scintillans, ballast waters, Western Indian Ocean
Abstract-A one-year study (July 2003 - June 2004) to explore the spatial and temporal variability of potentially harmful dinoflagellates was carried out in the central coastal waters of Tanzania. During the course of the study a green dinoflagellate, Noctiluca scintillans, which has cosmopolitan distribution, was encountered for the first time in the coastal waters of Tanzania. It demonstrated a clear temporal distribution with high biomass (up to 30 cells/l) during the northern monsoon period and showed significant negative correlation with temperature and salinity. Noctiluca scintillans was possibly introduced by ballast waters or currents and became established for at least one season, but later disappeared due to the physical-chemical environment and/or competition or predation from other organisms in the water column. The need for a monitoring programme for potentially harmful micro-algae, and introduced alien species in Tanzanian coastal waters, is justified.
\end{abstract}

\section{INTRODUCTION}

The dinoflagellate Noctiluca scintillans (MacCartney) Ehrenb. is characterized by having large, up to $2,000 \mu \mathrm{m}$, bladder shaped vegetative cells associated with an oral pouch in which are located the tentacle and one emergent flagellum (Lucas, 1982). Vertical movements of Noctiluca in the water column are due to active ionic regulation of the specific gravity. Potassium ions are accumulated in the cell sap relative to its concentration in seawater, whereas the concentrations of the heavier ions calcium and magnesium are reduced (see Elbrächter and Qi, 1998 and references therein). Noctiluca has no chloroplast, but may form symbiotic association with a photosynthetic green flagellate, Pedinomonas noctilucae (Sweeney, 1976). When the endosymbiont is present, Noctiluca can apparently thrive photosynthetically without the need for phagotrophic food uptake.
Noctiluca scintillans is known to have a cosmopolitan distribution and is found in all temperate, subtropical and tropical coastal waters (Elbrächter and Qi, 1998). In the Indian Ocean, blooms of Noctiluca scintillans have been reported from Indian waters (e.g. Subrahmanian, 1985; Devassy, 1989), in Hong Kong waters (Ho and Hodgliss, 1992), far offshore from the equatorial Indian Ocean (Taylor 1976), and more recently in the Indian waters again (Eashwar et al., 2001; Dharani et al., 2004). Adnan (1989) provided a review of the green Noctiluca blooms in Jakarta Bay, Indonesia.

In some cases fish kills have been associated with blooms of Noctiluca (e.g. Subrahmanian, 1985; Ho and Hodgliss, 1992). The fish kill may be caused by different mechanisms. In many cases oxygen depletion is proposed as the causative agent for fish kill (Subrahmanian, 1985; Ho and Hodgliss, 1992; Xie et al. 1993). Another possible mechanism 
of fish kill by Noctiluca may be through the release of ammonia (Okaichi and Nishio, 1976). This is particularly the case at the end of the blooms when Noctiluca no longer feed and accumulate ammonia in their cells before lysing.

Several studies (e.g. Bryceson, 1977; Lyimo, 1995; Lugomela, 1996; Wallberg et al., 1999; Lugomela et al., 2001) have reported on phytoplankton species composition in Tanzania coastal waters but did not report on the existence of Noctiluca scintillans in the area. This paper represents the first reported observation of this nuisance dinoflagellate in the coastal waters of Tanzania and presents its temporal distribution in the area in relation to some physical chemical environmental parameters.

\section{MATERIALS AND METHODS}

Samples for dinoflagellate identification and quantification were collected twice per month in Dar es Salaam station and once per month in Zanzibar station, between July 2004 and June 2005, from an outboard engine boat. Dar es Salaam station is located in the open waters near Mbudya Island while Zanzibar station is located in the open waters near Bawe Island (Fig. 1 \& 2). Samples were taken by concentrating 201 of surface seawater through a

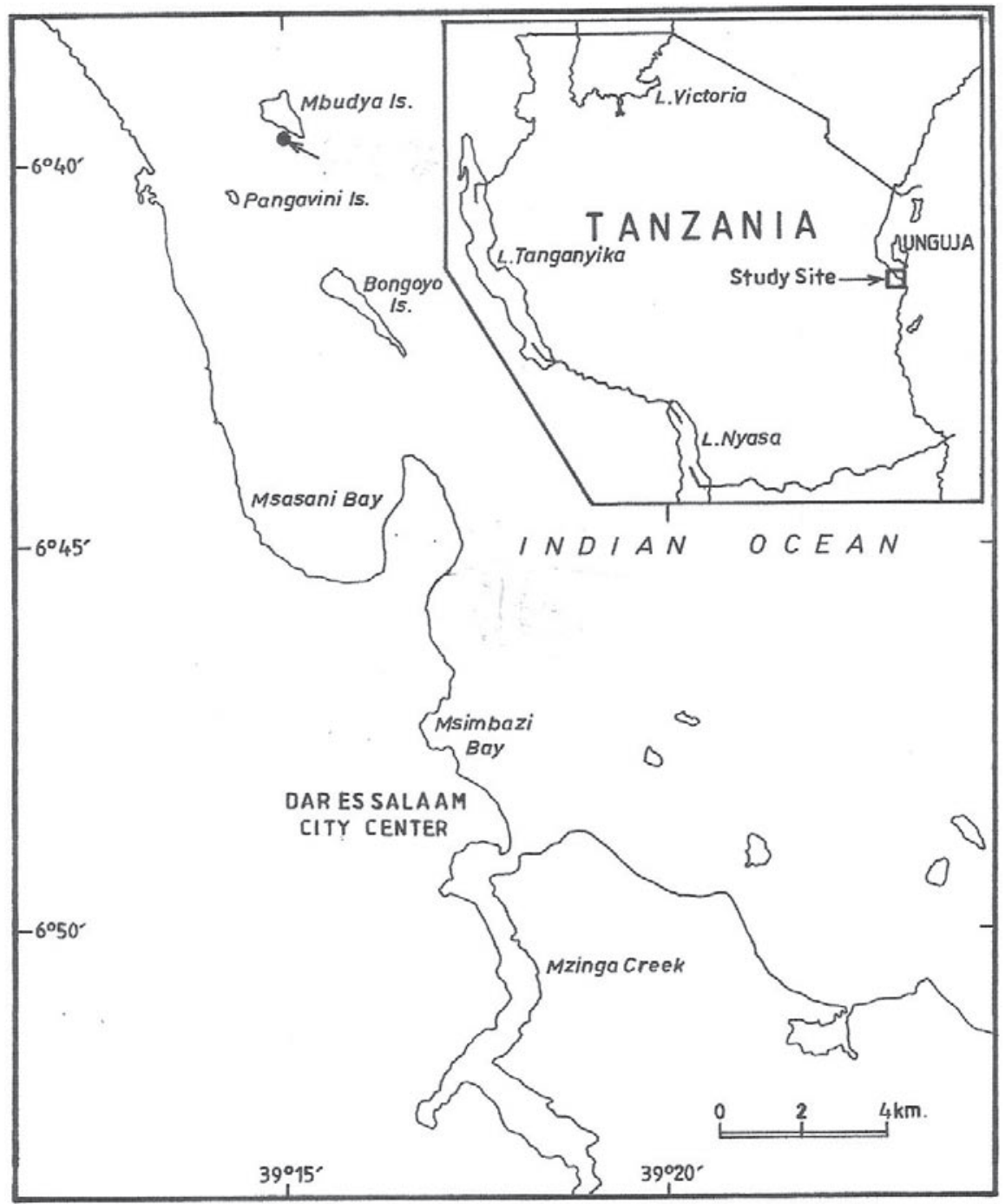

Fig. 1. Map of Dar es Salaam showing the sampling site (arrows) at Mbudya 


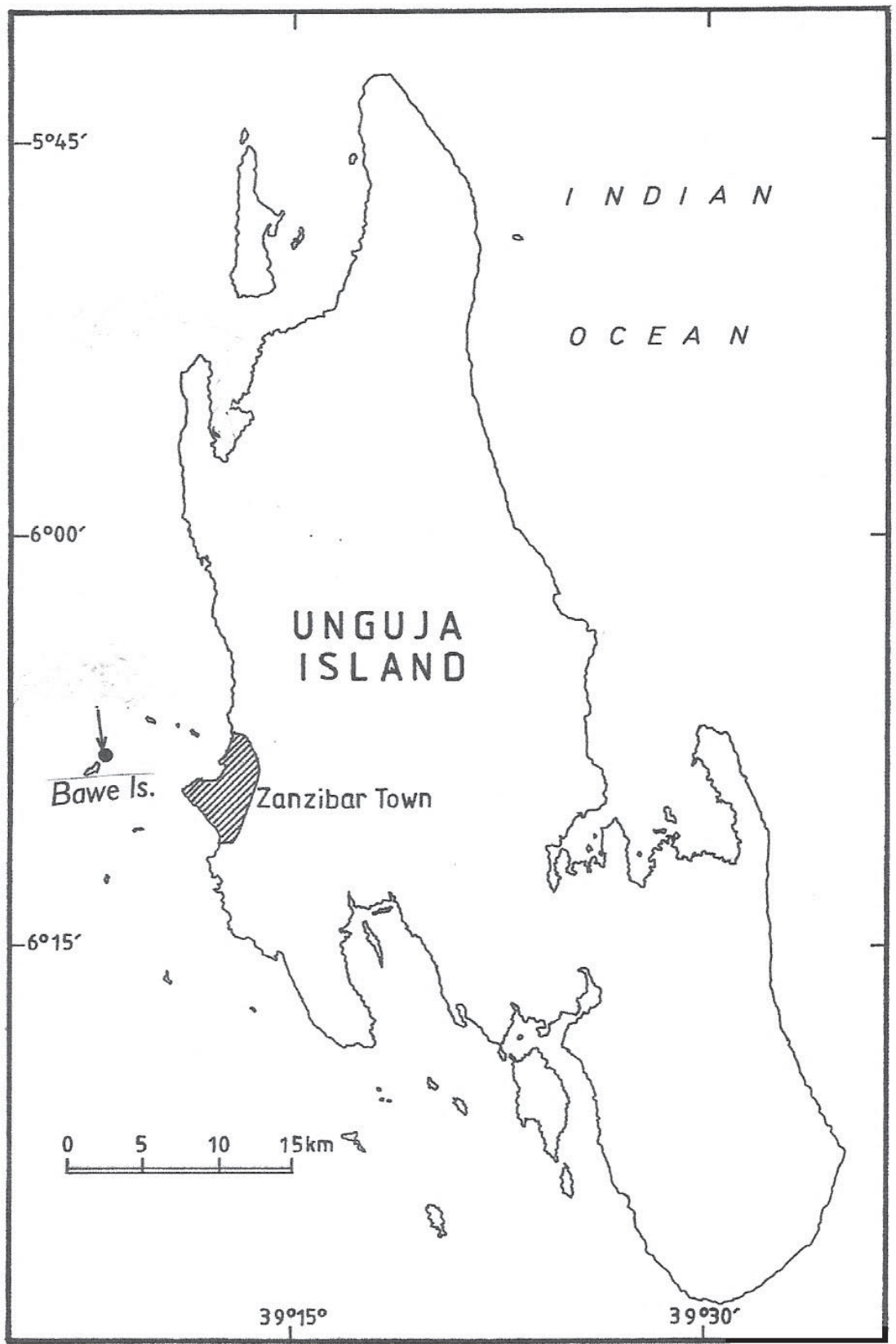

Fig. 2: Map of Zanzibar showing the sampling site (arrows) at Bawe.

$20 \mu \mathrm{m}$ mesh size plankton net into a $100 \mathrm{ml}$ volume dark glass sample bottle. The samples were then immediately fixed using acid Lugol's solution and brought to the laboratory. The dinoflagellated were counted in a Sedgewick-Rafter cell (Woelkerling et al., 1976).

Water samples were collected from each sampling site for nutrients $\left(\mathrm{NO}_{3}^{-}\right.$, and $\left.\mathrm{PO}_{4}^{+}\right)$ determination. The collected water was filtered through $0.22 \mu \mathrm{m}$ pore sized Millex-GS Millipore filters (France). The filtered water samples were kept in $50 \mathrm{ml}$ acid cleaned plastic vials and stored on ice for transport to a deep-freezing facility $\left(-20^{\circ} \mathrm{C}\right)$ to await analysis. Analyses for nitrate $\left(\mathrm{NO}_{3}^{-}\right)$, and phosphate $\left(\mathrm{PO}_{4}^{+}\right)$were undertaken using the methodology of Parsons et al. (1984). Two 
other environmental parameters, water temperature and salinity, were measured in the field using a thermometer and refractometer (ATAGO, Japan).

\section{RESULTS}

Water temperature at the sampling points ranged from $25.5^{\circ} \mathrm{C}$ in March 2004 at Mbudya station to $29.5^{\circ} \mathrm{C}$ during January 2004 at Mbudya (Fig. 3). Salinity varied only slightly ranging from $34.5 \mathrm{ppt}$ in March at Bawe to the highest value of $36 \mathrm{ppt}$ in September and October at Bawe and in November at Mbudya (Fig. 4). $\mathrm{PO}_{4}^{+}$concentration in the water column ranged from $0.21 \mathrm{nMol}^{+} \mathrm{PO}_{4}^{+} / 1$ at Mbudya during October and November 2003 to $26.4 \mathrm{nMol}$ $\mathrm{PO}_{4}^{+} / 1$ at Bawe in January 2004 (Fig. 5). $\mathrm{NO}_{3}^{-}$ concentration ranged from $23.2 \mathrm{nMol} \mathrm{NO}_{3}^{-/ 1}$ at Bawe in July 2003 to $81.9 \mathrm{nMol} \mathrm{NO}_{3}^{-/ 1}$ at Mbudya in February 2004 (Fig. 6). Significantly high nitrate concentration $(\mathrm{t}=3.02, \mathrm{p}=0.016)$ was observed

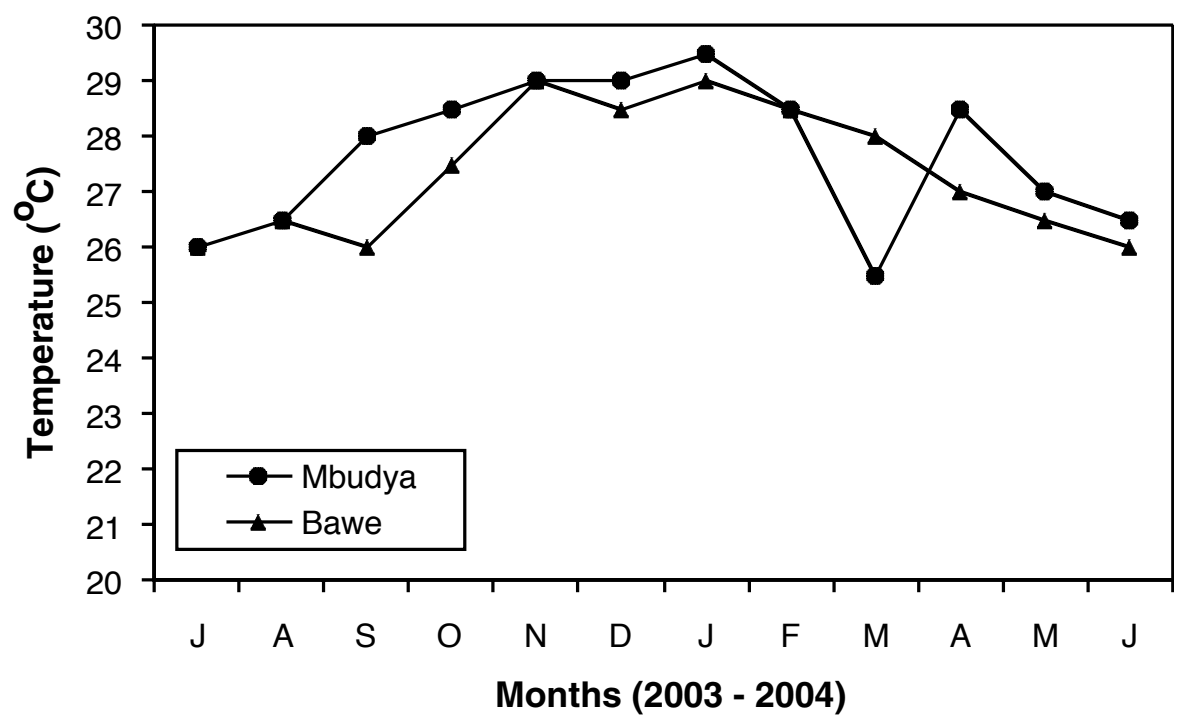

Fig. 3. Temperature variations in the water column during the study period

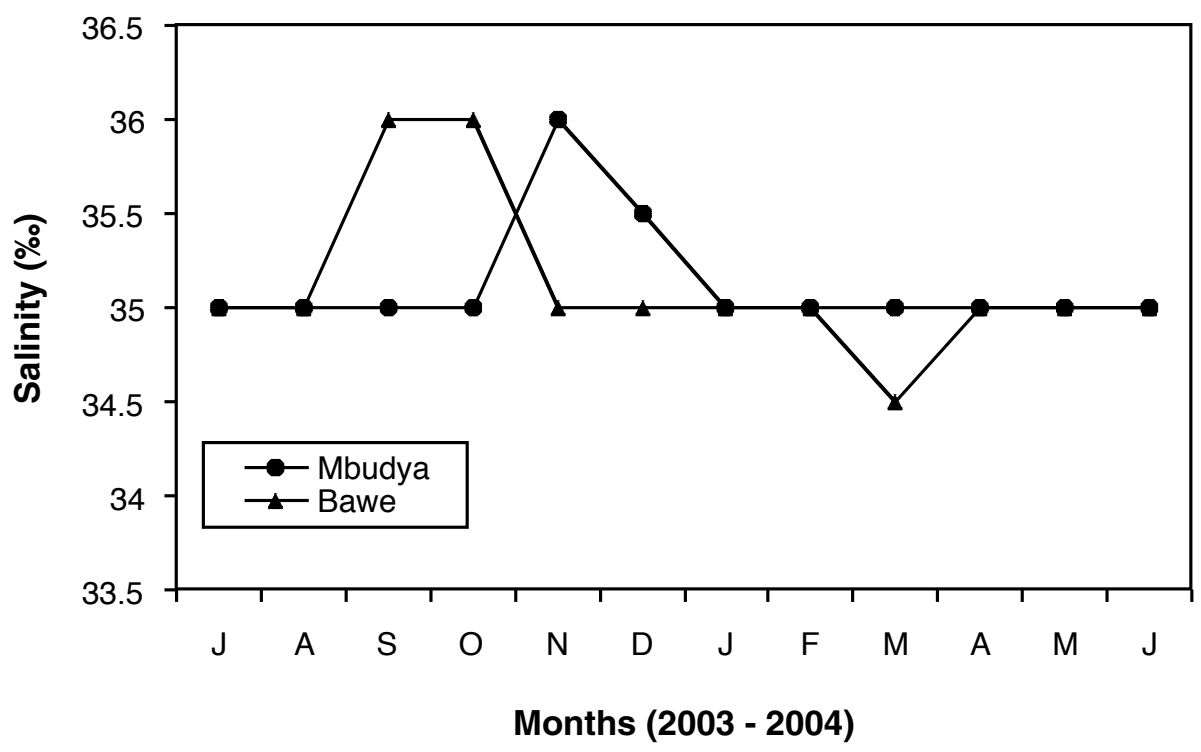

Fig. 4. Salinity variations in the water column during the study period 


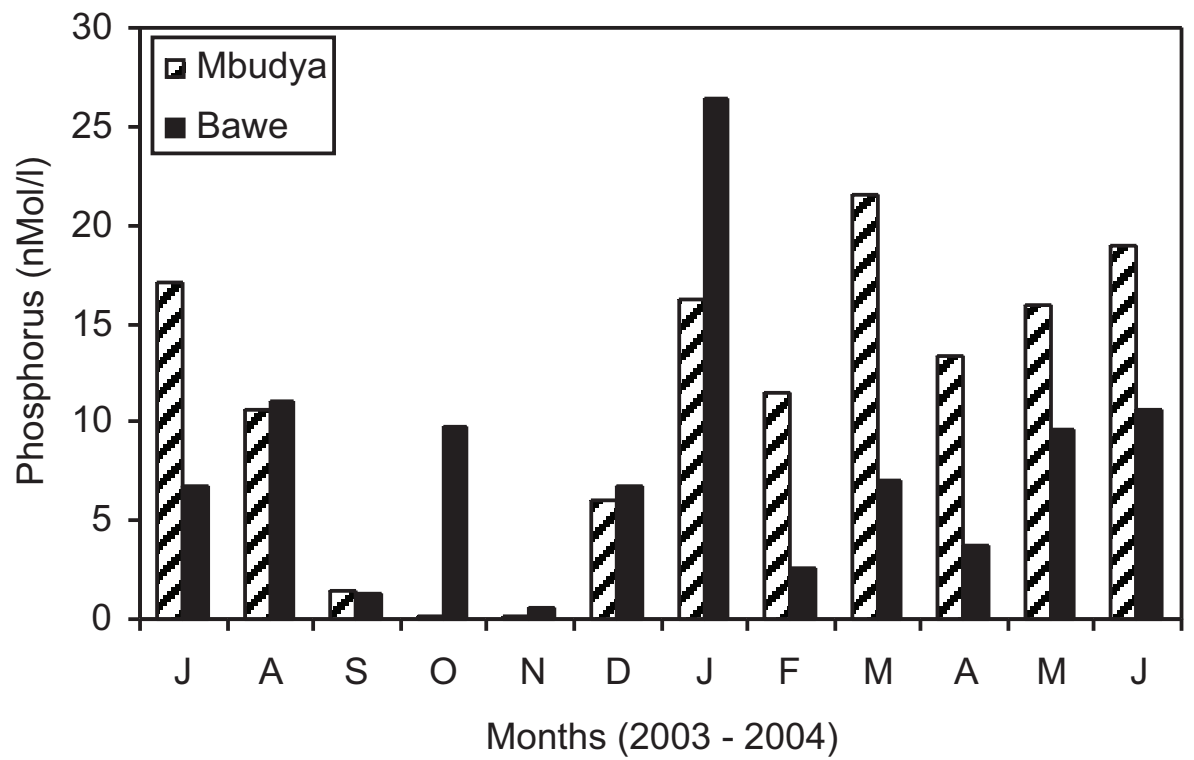

Fig. 5. Variations in soluble reactive phosphorus concentration in the water column during the study period

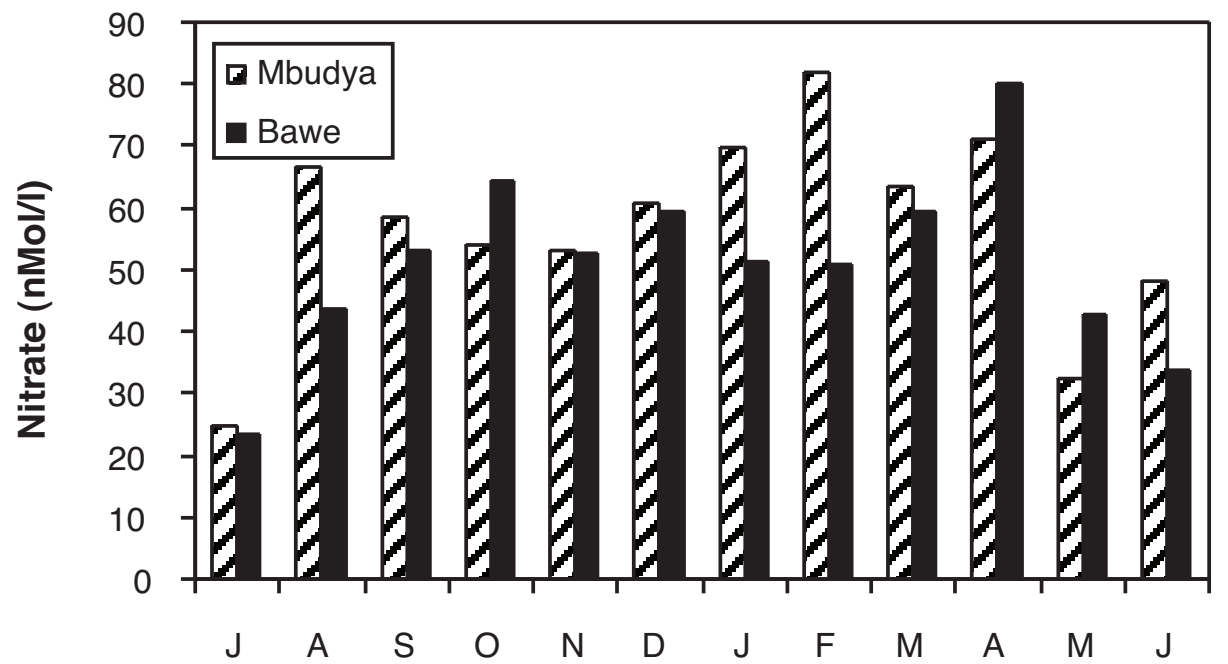

Months (2003 - 2004)

Fig. 6. Variations in nitrate concentration in the water column during the study period

during the northeast monsoon period (OctoberMarch) compared to the southern monsoon period (June-September).

Green Noctiluca scintillans with turbid cell contents (Plate 1) were encountered among plankton from both Mbudya and Bawe stations. The dinoflagellate showed a clear seasonal distribution appearing among the plankton during the northern monsoon period. The species reached a peak value of 30 cells per litre at Mbudya during March 2004 (Fig. 7). However, no Noctiluca scintillans was encountered in the study sites during the months of July to November (2003) and May to June (2004). Correlations between the biomass of Noctiluca scintillans and the various environmental parameters are given in Table 1. 


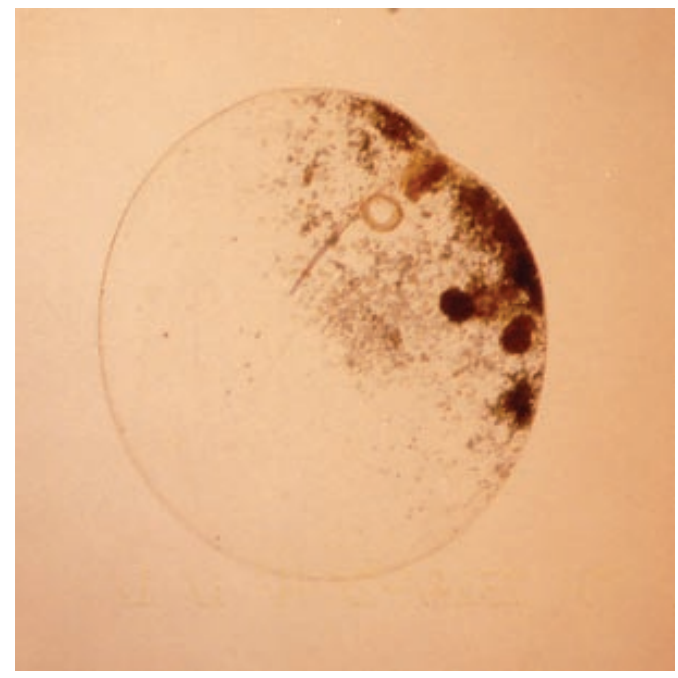

Plate 1: Photomicrograph of Noctiluca scintillans collected among plankton in the study area is similar to previous records in the area (e.g. Bryceson, 1977). Nutrient concentrations were also similar to previous records reported by Bryceson (1977) and Lugomela and Semesi (1996). Significantly higher nitrate concentrations in the water column were encountered during the northern monsoon period confirming earlier observations in the study areas (e.g. Bryceson, 1977; Lugomela and Semesi, 1996). Elevated nitrate concentration during the northern monsoon has been linked to nitrogen fixation by the planktonic colony forming cyanobacterium Trichodesmium spp., which is in high abundance during that period (Bryceson, 1977; Lyimo, 1995; Lugomela et al., 2002). In addition, the East Africa coastal current slows during the northern monsoon compared to the southern monsoon and increases the residence period of the water in the shelf and shallow environments,

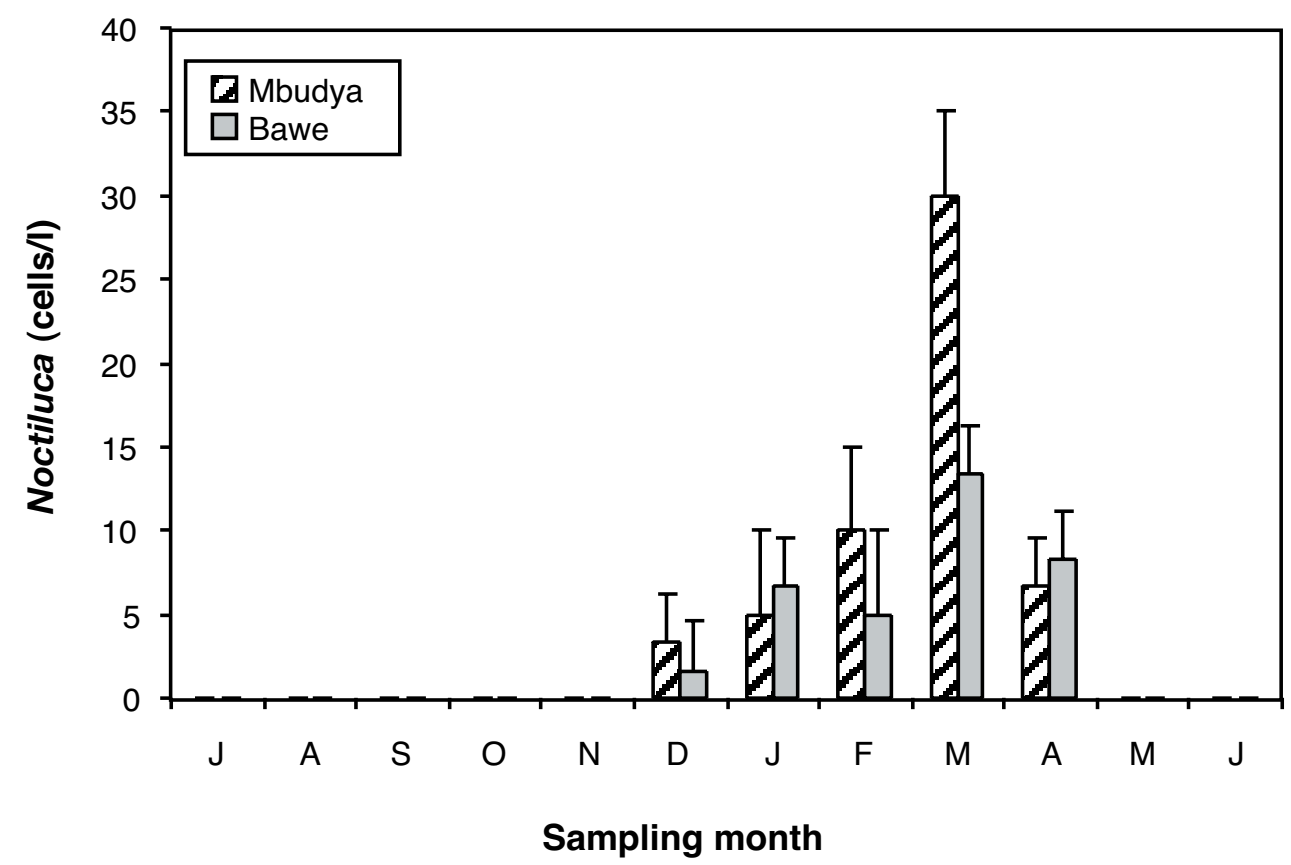

Fig. 7. Biomass of Noctiluca scintillans in the water column at Mbudya and Bawe during the study period (error bars $=$ standard deviation, $\mathrm{n}=3$ )

\section{DISCUSSION}

In general, low temperature values were recorded during the southern monsoon period (May to September) as compared to the northern monsoon period (November to March). This observation therefore waters acquire more neritic characteristics with increased nutrients (Bryceson, 1977). In general, nutrient values along the Tanzanian coast are low as a result phytoplankton blooms, apart from those of the nitrogen fixing cyanobacterium Trichodesmium species, have not been documented. 
Table 1. Correlations between the biomass of Noctiluca scintillans and the various environmental parameters in the water column at Mbudya and Bawe stations ( $r=$ Pearson's product-moment correlation coefficient, $p=$ probability of making type one error, $*=$ significant)

\begin{tabular}{llll}
\hline Station & Parameter & r values & p values \\
\hline Mbudya & Temperature & -0.9926 & $0.001^{*}$ \\
& Salinity & -0.3429 & $0.0104^{*}$ \\
& Phosphate & 0.9166 & $0.001^{*}$ \\
Bawe & Nitrate & -0.6397 & $0.001^{*}$ \\
& Temperature & -0.3199 & $0.05^{*}$ \\
& Salinity & -0.9058 & $0.001^{*}$ \\
& Phosphate & -0.185 & 0.287 \\
& Nitrate & 0.1442 & 0.4087 \\
\hline
\end{tabular}

However, with the apparent increase in pollution and eutrophication in the coastal waters of Tanzania (Mohammed, 2002), it is likely that such blooms may occur in the future.

The biomass of Noctiluca scintillans was low compared to that reported by Dharani et al. (2004) from Minnie Bay, India, and there were no signs of a bloom nor fish kills in this case. However, a significant negative correlation was observed between the biomass of Noctiluca scintillans and water temperature and salinity at both Mbudya and Bawe stations (Table 1) suggesting that this dinoflagellate does not perform well in waters with high temperatures and salinity. This is similar to the report by Huang and Qi (1997) in Dapeng Bay, South China Sea, from where these authors reported that the seasonal occurrence of Noctiluca occurred at water temperatures between $15.8^{\circ} \mathrm{C}$ to $28.6^{\circ} \mathrm{C}$, with that mass development at temperatures between 19 to $22^{\circ} \mathrm{C}$. This could explain why Noctiluca is not common in inshore waters, where temperature and salinity fluctuations are usually higher than those of oceanic water masses. There was also a significant negative correlation between the biomass of Noctiluca scintillans and concentrations of nitrate in the water column at Mbudya station. However, a significant positive correlation (Table 1) was observed between the biomass of Noctiluca and the concentration of phosphate in the water column at Mbudya station suggesting that phosphorus may also be a limiting factor for growth.
Noctiluca is regarded as one of the most common red-tide organism (Elbrächter and Qi, 1998), though it has never been reported before from the coastal waters of Tanzania (see e.g. Bryceson, 1977; Lyimo, 1995; Lugomela, 1996). The possibility exists that Noctiluca is not a native phytoplankton species in the area, but was introduced perhaps through ballast waters or ocean currents. Being mixotrophic, Noctiluca can remain viable in the dark ballast waters for long period and therefore easily transported over great distances (e.g. Hallegraeff, 1993, 1998). It disappeared with the onset of the southern monsoon and was not encountered again in subsequent phytoplankton samples from the area (Personal Observ.). That the dinoflagellate managed to establish for at least one season supports the introduction hypothesis, but the evidence also suggests that it might have been later out-competed by other organisms or eliminated due to inhospitable physical-chemical conditions. The occurrence of this potentially harmful dinoflagellate in Tanzanian waters supports the need for the establishment of a monitoring programme for this and other potentially harmful algal alien species.

Acknowledgement-I wish to express my sincere gratitude to the Western Indian Ocean Marine Sciences Association (WIOMSA) for providing the financial support that made this study a reality. Dr. Julius Francis, Mr. Hamad Chani and Mr. Seif Abdallah (WIOMSA) are strongly acknowledged for their useful correspondence and logistical support during the whole process of this study. I am indebted to the Faculty of Aquatic Sciences and Technology, University of Dar es Salaam for availing time to me to conduct this study. Thanks to the Department of Zoology and Wildlife Conservation and the Institute of Marine Sciences (IMS), Zanzibar for providing laboratory space and some logistical support. Mr. Augustine Mwandya, Juma Kangwe, Muhidin Abdallah and Idd Hamis (IMS, Zanzibar) are strongly acknowledged for their field assistance in Zanzibar. My thanks are also due to Mr. Yukundus P. Mhonda and Shelard Mukama for their assistance in the field whilst in Dar es Salaam. I also acknowledge the reviewers for their constructive comments. 


\section{REFERENCES}

Adnan, Q. (1989) Red tides due to Noctiluca scintillans (Maccartney) Ehrenb. and mass mortality of fish in Jakarta Bay. In: Okaich, T., Anderson, D.M., \& Nemoto, T. (eds) Red tides, biology, environmental science and toxicology. Elsevier Science Publishing B.V., pp. 53-55.

Bryceson, I. (1977) An ecological study of the phytoplankton of the coastal waters of Dar es Salaam. PhD thesis, University of Dar es Salaam.

Dharani, G., Abdul Nazar, A.K., Kanagu, L., Venkateshwran, P., Kumar, T.S., Ratnam, K. Venkatesan, R. and Ravindran, M. (2004) On the occurrence of Noctiluca scintillans bloom in Minnie Bay, Port Blair: Impact on water quality and bioactivity of extracs. Current Science, 87(7): 990 - 994.

Devassy, V.P. (1989) Red tide discolouration and its impact on fisheries. In: Okaich, T., Anderson, D.M., \& Nemoto, T. (eds) Red tides, biology, environmental science and toxicology. Elsevier Science Publishing B.V., pp. 57-60.

Eashwar, M., Nallathambi, T., Kuberraj, K. and Govindarajan, G. (2001) Noctiluca bloom in Port Blair Bay, Andamans. Current Science, 81(2): $203-206$.

Elbrächter, M. and Qi, Y.Z. (1998) Aspects of Noctiluca (Dinophyceae) population dynamics. In: Anderson, D.M., Cembella, A.D. \& Hallegraeff, G.M., (eds) Physiological ecology of harmful algal blooms. NATO ASI series G, Ecological Sciences vol. 41, Springer-Verlag, Berlin, pp. 315-335.

Hallegraeff, G.M. (1993) A review of harmful algal blooms and their apparent global increase. Phycologia, 32 (2): 79-99.

Hallegraeff, G.M. (1998) Transport of toxic dinoflagellates via ship's ballast water: bioeconomic risk assessment and efficacy of possible ballast water management strategies. Mar. Ecol. Prog. Ser. 168: 297-309.

Ho, K.C. \& Hodgliss, I.J. (1992) Severe fish kill in Hong Kong caused by Noctiluca scintillans. Red Tide Newslett. 5: 1-2.

Huang, C. \& Qi, Y. (1997) The abundance cycle and influence factors on red tide phenomena of Noctiluca scintillans (Dinophyceae) in Dapeng Bay, the South China Sea. J. Plankt. Res. 19: 303-318.

Lucas, A.I.N. (1982). Observations on Noctiluca scintillans Macartney (Ehrenb.) (Dinophyceae) with notes on an intracellular bacterium. $J$. Plankton Res. 4: 401-409.
Lugomela, C. (1996) Studies on phytoplankton in the near shore waters of Zanzibar. M.Sc. thesis, University of Dar es Salaam, Tanzania.

Lugomela, C., Lyimo, T.J., Bryceson, I., Semesi, A.K. \& Bergman, B. (2002) Trichodesmium in coastal waters of Tanzania: diversity, seasonality, nitrogen and carbon fixation. Hydrobiologia. 477: 1-13.

Lugomela, C. \& Semesi, A.K. (1996) Spatial and temporal variations of phytoplankton in Zanzibar near shore waters. In: Björk, M., Semesi, A.K., Pedersen, M. \& Bergman, B. (eds) Current Trends in Marine Botanical Research in the East African Region. Sida/SAREC, Stockholm, pp. 235- 251.

Lugomela, C., Wallberg, P. \& Nielsen, T.G. (2001) Plankton composition and cycling of carbon during the rainy season in a tropical coastal ecosystem, Zanzibar, Tanzania. J. Plankton. Res. 23 (10): 1121-1136.

Lyimo, T.J. (1995) Role played by phytoplankton cyanobacteria with an emphasis on Trichodesmium species in increasing nitrogen levels in the near shore waters of Tanzania. M.sc. Thesis, University of Dar es Salaam.

Mohammed, S.M. (2002) A review of water quality and pollution studies in Tanzania. Ambio, 32: 617-620.

Parsons TR, Maita Y. \& Lalli, M. (1984) A manual of chemical and biological methods for seawater analysis. Pergamon press, $173 \mathrm{pp}$.

Okaichi, T. \& Nishio, Y. (1976) Identification of ammonia as the toxic principle of red tide of Noctiluca miliaris. Bull. Plankt. Soc. Japan, 23: 25-30.

Subrahmanian, A. (1985) Noxious dinoflagellates in Indian waters. In: Anderson, D.M., White, A.W. and Baden, D.G. (eds.) Toxic dinoflagellates. Elsevier Publishing Co. New York, pp. 525-528.

Sweeney, B. (1976) Pedinomonas noctilucae (Prasinophyceae), the flagellate symbiotic in Noctiluca (Dinophyceae) in southeast Asia. $J$. Phycol. 12: 460-464.

Taylor, J.F.R. (1976) Dinoflagellates from the international Indian Ocean expedition. Bibliotheca Botanica, 132: 1-234.

Wallberg, P. Jonsson, P.R. \& Johnstone, R. (1999) Abundance, biomass and growth rates of pelagic microorganisms in a tropical coastal ecosystem. Aquat. Microb. Ecol. 18: 175-185.

Woelkerling, W.J., Kowal, R.R. \& Gough, S.B. (1976) Sedgewick-Rafter cell counts: a procedural analysis. Hydrobiologia, 48: 95-107.

Xie J., Li, J., Lu, S., Cheng, Q. \& Yang, L. (1993) Features of red tide caused by Noctiluca scintillans off Yantian coast within Dapeng Bay. Mar. Sci. Bull. 12: 1-6. 